ALTRUIS, e-ISSN 2620-5513, p-ISSN 2620-5505, Vol. 1, No. 1, April 2018

Abdimas Altruis : Jurnal Pengabdian Kepada Masyarakat

http://e-journal.usd.ac.id/index.php/ABDIMAS

Universitas Sanata Dharma, Yogyakarta

\title{
IbM Peternak Sapi Perah dan Pengolahan Susu di Pakem Sleman
}

\author{
${ }^{1)}$ Franciscus Asisi Joko Siswanto, ${ }^{2}$ Rubiyatno, ${ }^{3)}$ Yohanes Dwiatmaka \\ ${ }^{1)}$ Program Studi Akuntansi Fakultas Ekonomi, Universitas Sanata Dharma \\ 2) Program Studi Manajemen Fakultas Ekonomi, Universitas Sanata Dharma \\ ${ }^{3)}$ Program Studi Farmasi Fakultas Farmasi, Universitas Sanata Dharma \\ email: joko_sis@usd.ac.id \\ https://doi.org/10.24071/altruis.2018.010101
}

\begin{abstract}
Community service aims to make (a) the creation of a clean enclosure environment; clean water supply, availability of cattle breeding facilities, availability of standard and hygienic milking equipment, the achievement of milk that meets quality standards, availability of milk heating equipment, and the availability of cooling equipment for milk storage; (b) the creation of marketing networks of milk products, increased ability to use the Internet network for expansion of marketing, increased ability to manage finance through cash book entry and cash out, increasing ability of partner to operate computer-based financial application programs, obtain permission trade mark and entrepreneurship spirit for keeper of dairy cattle. After conducting discussion with Partners 1 and Partner 2, we provided the necessary trainings to help overcome the weaknesses of Partnerss. Partner's weaknesses were limited marketing of milk to cooperatives, cattle raising, simple pasteurization milk processing, business management/marketing, and bookkeeping and profit report creation. There were several steps that were taken, which included: cleaning training, milking training, pasteurized milk making training, business management training, bookkeeping training and production cost calculation, profit and loss calculation, and marketing management training. The results were providing facilities for activities and new markets that can increase revenues.
\end{abstract}

Keywords: higienis, pemasaran, susu sapi

\section{PENDAHULUAN}

Kegiatan usaha untuk meningkatkan produksi susu di Indonesia sejak tahun 1980 telah dikembangkan hingga saat ini. Namun demikian perkembangan kegiatan ini masih lambat karena kegiatan ini merupakan kegiatan sampingan yang dilakukan oleh para petani. Mereka belum merasakan manfaat ekonomi yang signifikan dalam kehidupan keluarga apabila kegiatan mereka berfokus pada peternakan sapi perah.Salah satu penyebabnya yaitu pendapatan penjualan susu belum bisa mencukupi kebutuhan keluarga karena harga jual susu yang relatif rendah dan dijual pada koperasi setempat. Mereka belum memiliki alternatif lain untuk memasarkan susu. Kegiatan koperasi ini memang mendukung para petani untuk memelihara sapi perah karena koperasi ini menyediakan indukan atau dara sapi-sapi perah yang bisa dimiliki oleh para petani dengan status hutang. Para petani memiliki hutang kepada koperasi sebesar harga sapi yang telah disepakati bersama antara koperasi dan petani pemelihara sapi. Untuk melunasi hutang tersebut, para petani mempunyai kewajiban menjual susu kepada koperasi. Apabila hutangnya sudah lunas, para petani memiliki kebebasan untuk menjual susu, artinya bisa menjual susu kepada koperasi atau kepada pihak lain. Kendala yang dihadapi oleh para petani yaitu mereka kesulitan mendapatkan pembeli lain karena pihak pembeli akan menentukan beberapa syarat yaitu kualitas susu, kandungan lemak, kandungan protein dan lainnya. Hasil produksi susu sapi perah yang ada di lereng Gunung Merapi pada umumnya masih banyak mengandung bakteri di atas batas normal. Batas normal bakteri standar yaitu rata-rata per liter mengandung 200.000 bakteri sedangkan susu yang diproduksi di lereng Merapi mengandung bakteri lebih dari 1.000.000 per liter. Untuk mengurangi kandungan bakteri diperlukan air bersih yang digunakan untuk membersihkan kandang, memandikan sapi, membersihkan puting sebelum diperah, dan lainya. Seperti kita ketahui susu merupakan suatu emulsi lemak dalam air yang mengandung beberapa senyawa terlarut. Agar lemak dan air dalam susu tidak mudah 
terpisah, maka protein susu bertindak sebagai emulsifier (zat pengemulsi). Kandungan air di dalam susu sangat tinggi, yaitu sekitar $87,5 \%$, dengan kandungan gula susu (laktosa) sekitar $5 \%$, protein sekitar 3,5\%, dan lemak sekitar 3-4\%. Susu juga merupakan sumber kalsium, fosfor, dan vitamin A yang sangat baik. Mutu protein susu sepadan nilainya dengan proteindaging dan telur, dan terutama sangat kaya akan lisin, yaitu salah satu asam amino esensial yang sangat dibutuhkan tubuh (Widodo, 2002).

Koperasi menjadi satu-satnya lembaga yang mau membeli susu sapi dari para petani walaupun kandungan bakterinya melebihi ambang batas standar. Namun demikian koperasi akan menentukan harga sesuai dengan kandungan bakteri yang ada. Apabila kandungan bakteri yang ada di dalam susu cukup tinggi, maka koperasi akan membeli dengan harga yang rendah, sekitar Rp 3.400 tetapi kakau kandungan bakteri yang ada dalam susu sapi relatif rendah maka koperasi akan membeli dengan harga yang cukup tinggi yaitu sekitar Rp 3.600 per liter.

Dalam transaksi penjualan susu ini biasanya dilakukan secara kredit, artinya para petani tidak langsung menerima uang dari transaksi ini. Pembayaran akan dilakukan kepada para petani dalam tenggang waktu satu minggu atau satu bulan sekali. Dari pihak koperasi akan mengumpulkan susu sapi dari petani pada tempat atau rumah yang telah disepakati bersama. Setelah susu terkumpul, selanjutnya susu dijual kepada perusahaan dengan harga yang telah disepakati bersama antara koperasi dan perusahaan. Penjualan ini juga dilakukan secara kredit karena perusahaan akan membayaar secara bulanan. Dengan demikian menjadi suatu hal yang wajar ketika para petani menerima pembayaran dari koperasi dalam tenggang waktu satu bulan sekali karena koperasi juga menerima pembayaran dari perusahaan sebulan sekali.

Proposal pengabdian yang dikemas dalam Ipteks bagi Masyarakat ini fokus pada petani pemelihara sapi perah di lereng Gunung Merapi, khususnya di daerah desa Purwobinangun dan Candibinangun, kecamatan Pakem. Secara geografis kedua desa tersebut dapat menjadi prioritas untuk pengembangan peternakan rakyat guna mendorong diversifikasi pangan dalam rangka mencukupi kebutuhan protein hewani, yaitu susu dan daging. Kedua desa tersebut memiliki keunggulan yang mendukung pengembangan sapi perah karena udara yang dingin, air melimpah, tanah subur, pemeliharaan sapi sudah dijalani bertahun-tahun dan turun temurun, pakan rumput mudah diperoleh, dan ada koperasi yang membeli susu.
Dalam pengabdian ini petani pemelihara sapi perah menjadi subyek dengan dasar pemikiran sebagai berikut: ada potensi peningkatan pendapatan, jumlah petani cukup banyak, pilihan tempat menjual susu tidak banyak, harga jual relatif rendah, kualitas susu dan kebersihan lingkungan kandang masih perlu ditingkatkan. Berdasarkan uraian tersebut kami mencari mitra yang bersedia membeli susu dengan harga yang wajar dan bersedia untuk mendampinginya sehingga ada peningkatan kualitas susu dan penurunan bakteri sampai pada standar normal. Mitra ini bergerak pada pengolahan susu dan pemasarannya. Namun demikian mitra ini juga masih perlu sentuhan pengetahuan, dan pelatihan sehingga mitra ini dapat menjadi salah satu tempat penjualan susu sapi bagi para petani pemelihara sapi perah. Pendapingan mitra ini menjadi penting agar mitra ini bisa berkembang dan mampu membeli susu dalam jumlah yang banyak sehingga dapat mendukung peningkatan kesejahteran para petani pemelihara sapi perah.

\section{Mitra 1}

Sr. Anastasia Darmini adalah orang yang memiliki kepedulian terhadap peningkatan tarap hidup masyarakat kecil dan ekonomi lemah baik yang sedang dilanda bencana alam maupun yang berusaha meningkatkan kemandirian hidup. Masyarakat kecil dan lemah biasanya sulit untuk bisa bangkit kalau tidak ada yang memberikan pengarahan dan pendampingan yang teratur. Dalam rangka mewujudkan cita-cita meningkatkan tarap hidup masyarakat tersebut, $\mathrm{Sr}$ Anastasia Darmini bekerjasama dengan beberapa orang untuk membeli susu sapi perah dari petani pemelihara sapi perah di daerah Purwobinangun, Sleman. Susu sapi tersebut dibeli dengan harga yang lebih tinggi bila dibandingkan dengan harga yang dijual kepada koperasi pengepul susu. Selisih harga tersebut dapat mendongkrak pendapatan pemelihara sapi perah sehingga dapat meningkatkan tarap hidup mereka. Selanjutnya susu sapi tersebut dimasak agar bisa dijual dalam kemasan gelas susu. Penjualan susu kemasan ini dimaksudkan untuk membantu peningkatan kesehatan masyarakat karena ada kandungan protein dalam susu sapi yang dapat meningkatkan kesehatan. Susu merupakan minuman bergizi tinggi yang dihasilkan ternak perah menyusui, seperti sapi perah, kambing perah, atau bahkan kerbau perah. Susu sangat mudah rusak dan tidak tahan lama di simpan kecuali telah mengalami perlakuan khusus. Susu segar yang dibiarkan di kandang selama beberapa waktu, maka lemak susu akan menggumpal di permukaan berupa krim susu, kemudian bakteri perusak susu yang bertebaran di udara kandang, yang berasal dari sapi 
masuk ke dalam susu dan berkembang biak dengan cepat. Oleh bakteri, gula susu di ubah menjadi asam yang mengakibatkan susu berubah rasa menjadi asam. Lama kelamaan susu yang demikian itu sudah rusak. Kombinasi oleh bakteri pada susu dapat berasal dari sapi, udara, lingkungan, manusia yang bertugas, atau peralatan yang digunakan seperti dikemukakan oleh Sumoprastowo (Rizky, 2014: 4)

Pemrosesan susu dari petani menjadi fokus kegiatan Sr Anastasia karena melalui kegiatan ini dia akan dapat berkontribusi dalam peningkatan tarap hidup masyarakat dan dapat memberikan harapan baru bagi masyarakat untuk menekuni ternak sapi perah. Dalam pengamatan Sr Anastasia selama bergaul dan berkarya pada lingkungan masyarakat kecil, $\mathrm{Sr}$ Anastasia menemukan bahwa 1) anak-anak muda lebih tertarik meninggalkan kampung halaman untuk mendapat pekerjaan di kota-kota besar yang dianggap lebih menjanjikan, 2) tanah-tanah sawah mulai dijual kepada pemilik modal dan tidak diolah untuk pertanian, 3) kemampuan mengolah tanah berdasarkan pada pengalaman masa lalu (tradisional atau konservatif) dan kurang mendapat sentuhan pengetahuan yang modern, 4) kurang memperhatikan pelestarian lingkungan hidup, (5) kurang fokus serta tekun pada pemeliharaan sapi perah, dan (6) tidak memiliki alternatif penjualan susu dengan harga yang lebih baik.

Keinginan dan niat Mitra ini sangat bagus, namun masih perlu dibenahi karena masih memiliki banyak kelemahan yaitu a) dalam bidang pemrosesan, b) pemberian merek, c) pengepakan, d) pemasaran, e) pencatatan transaksi dan f) pengelolaan sumber daya manusia. Namun demikian Mitra ini memiliki keunggulan yaitu memiliki tim yang terdiri dari orangorang yang memiliki hati dan semangat untuk membantu meningkatkan tarap hidup masyarakt petani pemelihara sapi perah serta semangat untuk menambah pengetahuan dan memperbaiki yang dianggap kurang. Hal ini dapat dijelaskan sebagai berikut: (1) Dalam bidang pemrosesan. Sr Anastasia masih menggunakan alat-alat pemrosesan yang sederhana sehingga masih kurang efisien dan kurang standar.Ada kompor gas untuk memasak susu, panci untuk tempat susu yang akan dimasak, sirup untuk memberi rasa. Ada gelas plastik untuk tempat susu cup, ada panci untuk tempat susu yang sudah siap dimasukkan dalam cup gelas, ada gayung untuk mengukur volume dan menuangkan pada cup gelas, dan ada alat pengepakan secara manual; (2).Dalam pemberian merek. Sr Anastasia sudah memberi merek, tapi merek ini belum didaftarkan resmi di BPOM; (3).Dalam pengepakan. Pengepakan dilakukan secara sederhana, sehingga kadang masih ada yang bocor; (4). Dalam bidang pemasaran. Pemasaran masih terbatas pada relasi-relasi dekat sehingga belum menembus pasar potensial; (5). Dalam pencatatan transaksi; (6). Pencatatan transaksi belum tertib sehingga ada transaksi yang tidak dicatat; (7). Dalam pengelolaan sumber daya manusia. Sumber daya manusia masih relatif baru semua sehingga masih perlu diberi pelatihan yang cukup.

\section{Mitra 2}

Bapak Petrus Sokodi dan Bapak Siswanto adalah anggota kelompok tani sapi perah di dusun Kemiri, Purwobinangun. Mereka memelihara sapi perah sejak tahun 1988 hingga saat ini. Selama jangka waktu 25 tahun beternak sapi perah tentu mereka mempunyai banyak pengalaman. Pada awalnya mereka hanya ingin memiliki sapi perah karena ingin memperoleh pendapatan yang lebih besar apabila dibandingkan dengan beternak kambing dan lainnya. Hasil dari ternak sapi perah tersebut ternyata dapat memberi harapan baru sehingga para tetangga juga mulai tertarik beternak sapi perah. Saat ini petani yang beternak sapi perah cukup banyak, lebih dari 20 orang yang terbagi dalam dua kelompok. Mereka membentuk kelompok sesuai dengan sponsor yang memberi pinjaman dalam ujud sapi perah. Kebetulan di dusun kemiri ada dua sponsor yang memberi pinjaman sapi perah. Pada umumnya mereka memiliki sapi perah antara 3 ekor sampai 5 ekor.

Awalnya mereka memperoleh pinjaman yang diwujudkan 1 ekor sapi dari koperasi. Pinjaman ini dituangkan dalam suatu ikatan perjanjian antara petani dan koperasi. Ikatan perjanjian yang ada, yaitu para petani mempunyai kewajiban menjual susu sapi ke koperasi dengan harga yang ditentukan oleh koperasi sebagai bagian tanggungjawab untuk mengangsur hutang pada koperasi. Harga susu tergantung pada kualitas susu. Semakin berkualitas, harga susu semakin mahal. Hasil penjualan susu dipotong untuk mengangsur pinjaman sesuai dengan kesepakan antara petani dan koperasi. Apabila hutang pada koperasi telah lunas, petani memiliki kebebasan menjual jual susu, yaitu bisa menjual susu kepada koperasi atau kepada pihak lain. Sampai dengan saat ini mereka tidak memilik alternatif lain, selain menjual susu kepada koperasi.

Situasi seperti inilah yang mendorong kami untuk membantu memberikan alternatif lain dengan membuka pasar baru sehingga mereka dapat menjual sebagian susunya kepada pihak lain dengan harga yang lebih mahal. Agar bisa menjual susu kepada pihak lain, ada beberapa hal yang perlu dikaji ulang yaitu mengenai kecukupan air, pola pemberian pakan, 
kebersihan lingkungan kandang, jenis pakan yang diberikan, tempat untuk menyimpan susu, dan pengukuran kualitas susu secara berkelanjutan.

Permasalahan yang dihadapi oleh para petani yaitu kualitas susu yang belum memenuhi standar. Berdasarkan pengamatan, para petani memiliki permasalahan, yaitu: pelaksanaan pemerahan masih kurang higienis, susu yang dihasilkan kurang bersih, dan berat jenis susu rendah.

Permasalahan tersebut bisa disebabkan oleh beberapa hal antara lain: (1). Berat jenis yang rendah disebabkan oleh faktor pakan; (2). Kualitas susu yang kurang baik disebabkan oleh pelaksanaan pemerahan yang kurang higienis dan penggunaan peralatan yang tidak memenuhi persyaratan.Untuk mengatasi masalah tersebut perlu dilakukan beberapa langkah: (1). Mengadakan penyuluhan secara langsung di kandang berkaitan dengan pelaksanaan pemerahan, penggunaan peralatan yang bersih untuk menampung susu, pengeringan puting setelah dicuci dengan kain bersih dan kering, membuang pancaran susu pertama pada pemerahan; (2). Pendampingan untuk meningkatkan kebersihan dan berat jenis susu; (3). Pendampingan penyediaan pakan konsentrat, (4). Pendampingan pada kelompok anggota gapoktan yang lain; (5). Membangun kerjasama dengan pengolah susu.

Apabila proses pembinaan tersebut telah selesai dilaksanakan, maka diharapkan kualitas susu memenuhi standar. Dengan kualitas susu yang baik, petani peternak sapi perah akan dapat menjual susu pada pihak lain dengan harga yang lebih tinggi apabila dibandingkan dengan harga koperasi. Hasil produksi Mitra adalah susu sapi segar dan susu sapi pasturisasi dalam kemasan. Harga susu sapi segar saat ini sekitar Rp 4.000 per liter sedangkan susu sapi pasturisasi Rp 2.000 per gelas ukuran 160 cc. Apabila dikaitkan dengan lingkungan lingkungan hidup, maka Mitra ini mempunyai kontribusi dalam pelestarian lingkungan hidup baik bagi masyarakat Purwobinangun, Candibinangun dan masyarakat desa-desa sekitarnya.

\section{METODE}

Solusi yang ditawarkan kepada Mitra 1 dan Mitra 2 dengan pendekatan partisipasi, artinya Mitra 1 dan Mitra 2 diajak diskusi dan tanya jawab untuk menemukan solusi. Pendekatan partisipatif digunakan agar mitra ikut berpartisipasi secara aktif terhadap semua kegiatan mulai dari awal sampai akhir. Keunggulan pendekatan ini, yaitu Mitra 1 dan Mitra 2 akan menemukan solusi sendiri sehingga kuptusannya juga dibuat sendiri.

Beberapa pendapat tentang definisi partisipasi yang pada dasarnya mempunyai arti yang hampir sama, antara lain berikut ini: Upaya terorganisasi untuk meningkatkan pengawasan terhadap sumber daya dan lembaga pengatur dalam keadaan tertentu, oleh berbagai kelompok dan gerakan yang dikesampingkan dari fungsi pengawasan oleh Stiefel dan Wolfe (Asnudin, 2010). Suatu proses dimana para pemilik kepentingan (Stakeholders) mempengaruhi dan berbagi pengawasan atas inisiatif dan keputusan pembangunan serta sumber daya yang berdampak pada mereka menurut World Bank(Asnudin, 2010)

Tahapan yang dilakukan secara umum adalah mengidentifikasi keunggulan, kelemahan dan peluang serta mencari solusi untuk mengatasi kelemahan. Adapun langkah-langkah, yaitu: Mengidentifikasi Keunggulan yang dimiliki oleh Mitra 1 dan Mitra 2; (2). Mengidentifikasi Kelemahan yang ada pada Mitra 1 dan Mitra 2; (3). Mengidentifikasi Peluang pemasaran susu pada Mitra 1 dan Mitra 2. (4). Mencari Solusi untuk mengatasi kelemahan yang dimiliki oleh Mitra 1 dan Mitra 2 sehingga bisa memperoleh pasar baru.

Setelah melakukan diskusi bersama Mitra 1 dan Mitra 2 kami akan memberikan pelatihan-pelatihan yang diperlukan untuk membantu mengatasi kelemahan yang dimiliki oleh Mitra 1 dan Mitra 2. Rencana kegiatan pelatihan ini meliputi: (1). Pelatihan membersihkan kandang; (2). Pelatihan pemerahan susu; (3). Pelatihan pembuatan susu pasturisasi; (4). Pelatihan kewirausahaan dan manajemen usaha; (5). Pelatihan pembukuan dan menghitung harga pokok produksi; (6). Pelatihan manajemen pemasaran.

Selama kegiatan pelatihan berlangsung, mitra diharapkan selalu ikut berpartisipasi secara aktif. Partisipasi mitra yang diharapkan selama kegiatan yaitu meliputi: (1). Kesadaran memahami permasalahan yang ada dan dimiliki oleh Mitra; (2). Menemukan kebutuhan nyata yang berkaitan dengan kegiatan usaha yang dijalani oleh Mitra; (3). Mencari solusi guna memecahkan permasalahan; (4). Mencari pasar baru yang bisa meningkatkan pendapatan; (5). Menyediakan fasilitas tempat kegiatan; (6). Memasarkan produk susu; (7). Mendaftarkan merek di BPOM

\section{HASIL DAN PEMBAHASAN}

Kegiatan Sosialisasi disepakati dan dilasanakan tanggal 17 April 2015, bertempat di rumah bapak Sokidi dan dihadiri oleh mitra 1 dan mitra 2, serta anggota kelompok peternak sapi. Dalam pertemuan diketahui bahwa jumlah aktif anggota kelompok ada orang 17 peternak, dengan jumlah sapi 40 ekor. Dalam pertemuan tersebut disepakati rangkaian kegiatan IbM, yang meliputi: survei keadaan 
peternak, pelatihan membersihkan kandang, pelatihan pemerahan susu, pelatihan menguji kualitas susu, pelatihan pemberian pakan, pelatihan pembuatan susu pasteurisasi, pelatihan kewirausahaan dan manajemen usaha, pelatihan pembukuan dan menghitung harga pokok produksi dan pelatihan manajemen pemasaran.

Dalam pelaksanaan program ini tidak hanya melibatkan para anggota peternak tetapi juga masyarakat, maka dampak kegiatan tidak hanya dirasakan oleh Mitra 1 dan Mitra 2 saja. Dengan demikian baik secara langsung dan tidak langsung kegiatan IbM ini akan berdampak luas. Dalam praktek keseharian para peternak tidak mendapatkan harga sesuai dengan kualitas susu sapi yang dimiliki oleh para peternak tetapi harga dibuat sesuai dengan kualitas susu rata-rata per kelompok peternak. Susu dari para peternak dikumpulkan dalam satu kelompok baik yang kualitas jelek maupun bagus. Susu tersebut kemudian diukur kualitas rata-ratanya untuk menentukan harga jual dari peternak. Kkualitas susu yang jelek dari beberapa peternak akan berdampak bagi semua peternak. Oleh karena itu dampak perbaikan kualitas susu dari adanya program IbM ini sungguh akan memberikan potensi perbaikan harga, setidaknya daya tawarharga yang dimiliki oleh peternak akan meningkat, dan seluruh kegiatan yang telah direncanakan dapat berjalan dengan baik. Dari sisi jumlah susu yang diterima oleh Mitra 2 tentu saja denganharga yang lebih tinggi dan permintaan susu dari bulan ke bulan juga terjadi peningkatan.

Dalam kegiatan ini ada indikator capean baik aspek produksi maupun aspek manajemen. Kedua indikator capean dituangkan dalam Tabel 1 dan 5 . Kedua aspek tersebut akan dibahas secara mendetal agar memberikan gambaran yang nyata mengenai kegiatan yang dilakukan.

\section{Pembahasan Aspek Produksi}

Pembahasan aspek produksi meliputi kebersihan lingkungan kandang, kelengkapan saran penunjang, peralatan pemerahan yang higiens, kualitas susu, peralatan pemanas, alat pendingin penyimpanan susu. Tabel 1 menunjukkan indikator keberhasilan aspek produksi.

Tabel 1. Indikator Keberhasilan Aspek Produksi

\begin{tabular}{clll}
\hline No. & \multicolumn{1}{c}{ Hasil } & \multicolumn{1}{c}{ Dasar } & \multicolumn{1}{c}{ Target } \\
\hline 1 & Kebersihan lingkungan kandang & Lingkungan kandang kotor & Lingkungan kandang bersih \\
\hline 2 & Kelengkapan sarana penunjang & $\begin{array}{l}\text { Kelengkapan sarana penunjang } \\
\text { sudah ada namun belum sesuai }\end{array}$ & $\begin{array}{l}\text { Kelengkapan sarana penunjang yang } \\
\text { baku }\end{array}$ \\
\hline 3 & $\begin{array}{l}\text { Peralatan untuk pemerahan yang } \\
\text { standar dan higienis }\end{array}$ & $\begin{array}{l}\text { Peralatan pemerahan sudah ada tapi } \\
\text { belum higienis dan standar }\end{array}$ & Peralatan yang higienis dan standar \\
\hline 4 & $\begin{array}{l}\text { Susu yang memenuhi standar } \\
\text { kualitas }\end{array}$ & Kualitas Susu dibawah standar & Kualitas Susu memenuhi standar \\
\hline 5 & $\begin{array}{l}\text { Peralatan proses pemanasan susu } \\
\text { tapi sangat kecil }\end{array}$ & $\begin{array}{l}\text { Peralatan pendingin untuk } \\
\text { penyimpanan susu }\end{array}$ & $\begin{array}{l}\text { Peralatan pendingin menggunakan } \\
\text { kultas rumah tangga, yang hanya } \\
\text { mampu menyimpan 200 cup susu }\end{array}$ \\
\hline & & $\begin{array}{l}\text { Peralatan pendingin yang mampu } \\
\text { menyimpan 1.000 cup susu }\end{array}$ \\
\hline
\end{tabular}

Salah satu aspek permasalahan mendasar dalam aspek produksi yaitu bagaimana meningkatkan kualitas susu. Kualitas susu yang baik berarti aspek produksi terpenuhi yaitu sesuai standar kualtias susu nasional. Kualitas susu yang rendah atau jelek berdampak pada harga jual jual susu yang rendah yaitu
Rp 4.000,- perliter. Kualitas susu ada rata-rata berada di bawah berat jenis (BJ) standar nasional. Rata-rata BJ susu peternak sebelum pendampingan yaitu sebesar 1,0270 berada di bawah standar berat jenis standar nasional yaitu 1,0280. Tabel 2 adalah standar nasional kualitas

susu.

Tabel 2. Beberapa Persyaratan Utama Kualitas Susu Menurut SNI 01-3141-1998

\begin{tabular}{ll}
\hline \multicolumn{1}{c}{ Karakteristik } & \multicolumn{1}{c}{ Syarat } \\
\hline a. Berat jenis, minimum & 1,0280 \\
b. Uji alkohol $(70 \%)$ & Negatif \\
c. Warna, bau, rasa dan kekentalan & tidak ada perubahan \\
\hline
\end{tabular}


Dalam kegiatan pengabdian ini, para peternak didampingi agar berusaha untuk meningkatkan berat jenis sesuai dengan standar nasional sehingga harga jual susu dapat meningkat. Hasil pendampingan menunjukan ada peningkatan kualitas susu rata-rata dari yang sebelumnya rata-rata kualitas berat jenis 1,0270 menjadi 1,0291. Sedangkan warna, bau, rasa dan kekentalan menjadi normal dan gurih

.Tabel 3. Perbandingan hasil uji lab dan standar kualitas susu menurut SNI 01-3141-1998

\begin{tabular}{lcc}
\multicolumn{1}{c}{ Karakteristik } & Syarat & $\begin{array}{c}\text { Hasil uji lab rata-rata setelah } \\
\text { pendampingan }\end{array}$ \\
\hline $\begin{array}{l}\text { a. Berat jenis, } \\
\text { minimum }\end{array}$ & 1,0280 & 1,0291 \\
$\begin{array}{l}\text { b. Uji alkohol (70\%) } \\
\begin{array}{l}\text { c. Warna, bau, rasa } \\
\text { dan kekentalan }\end{array}\end{array}$ & Negatif & Negatif \\
\hline
\end{tabular}

Peningkatan kualitas susu berdampak pada peningkatan harga jual susu ke mitra 1 dan pihak luar. Harga susu menjadi Rp 6.000 per liter. Dengan demikian ada kenaikan harga $50 \%$ dari harga semula Rp 4.000 menjadi Rp 6.000.

Tabel 4 menunjukkan perkembangan permintaan susu dari Mitra 1 ke Mitra 2 Tahun 2015

Tabel 4.Jumlah permintaan susu oleh Mitra 1 (dalam liter) April sd Oktober 2015

\begin{tabular}{lllllll}
\hline Apri & Mei & Juni & Juli & Agust & Sep & Okto \\
\hline 150 & 200 & 400 & 125 & 550 & 850 & 800 \\
\hline
\end{tabular}

Dalam bulan Juli terjadi penurunan permintaan karena jumlah permintaan susu pasteurisasi menurun yang disebabkan oleh liburan sekolah. Susu tersebut oleh Mitra 1 diolah dalam bentuk pasteurisasi dan dikemas dalam gelas ukuran $160 \mathrm{cc}$.

Untuk menjaga kualitas susu, beberapa peralatan juga diserahkan kepada kelompok peternak yaitu berupa : sepatu kandang, alat uji Beerat Jenis, uji alkohol, peralatan pemanas susu pasteurisasi, dan lemari pendingin. Gambar 1 merupakan alat uji berat jenis dan uji alkohol yang diserahkan ke Mitra 2.

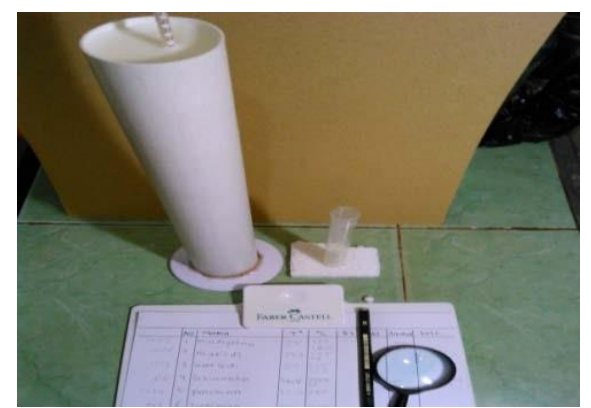

Gambar 1. Alat Uji Berat Jenis dan Uji Alkohol yang diserahkan ke Mitra 2

\section{Pembahasan Aspek Manajemen}

Pembahasan aspek manajemen meliputi :

Membangun jaringan pemasaran, pemanfaatan internet, pengelolaan keuangan, merk dagang dan kewirausahaan. Tabel 5 merupakan indikator capean aspek manajemen.

Tabel 5. Indikator keberhasilan aspek manajemenusaha kecil

\begin{tabular}{clll}
\hline No. & Hasil & Dasar & Target \\
\hline 1 & $\begin{array}{l}\text { Kemampuan membangun } \\
\text { jaringan }\end{array}$ & Belum memiliki jaringan & Ada jaringan pemasaran baru \\
\hline 2 & $\begin{array}{l}\text { Kemampuan menggunakan } \\
\text { internet }\end{array}$ & $\begin{array}{l}\text { Belum bisa menggunakan } \\
\text { internet }\end{array}$ & $\begin{array}{l}\text { Dapat menggunakan internet } \\
\text { untuk mengembangkan pasar }\end{array}$ \\
\hline 3 & Kemampuan mengelola uang & Belum ada pencatatan & $\begin{array}{l}\text { Ada catatan kas masuk dan } \\
\text { kas keluar }\end{array}$ \\
\hline 4 & $\begin{array}{l}\text { Kemampuan mengoperasikan } \\
\text { program aplikasi keuangan }\end{array}$ & $\begin{array}{l}\text { Belum pernah menggunakan } \\
\text { program aplikasi komputer }\end{array}$ & $\begin{array}{l}\text { Dapat menggunakan program } \\
\text { aplikasi komputer }\end{array}$ \\
\hline 5 & Merk Dagang & $\begin{array}{l}\text { Ada merek tapi belum } \\
\text { didaf-tarkan }\end{array}$ & $\begin{array}{l}\text { Mendaftarkan merk di } \\
\text { BPOM }\end{array}$ \\
\hline 6 & Semangat Wirausaha & Masih rendah & $\begin{array}{l}\text { Semangat selalu ingin } \\
\text { mengembangkan usaha }\end{array}$ \\
\hline
\end{tabular}

Dalam aspek manajemen, permasalahan yang mendasar yaitu bagaimana meningkatan penjualan susu yang sudah memenuhi standar kualitas nasional. Jalur pemasaran susu yaitu susu dari peternak sapi dijual ke Mitra 1 untuk diolah pasteurisasi. Susu pasteurisasi dijual ke sekolah-sekolah yang menjadi 
pelanggan Mitra 1. Dengan demikian peran Mitra 1 menjadi penting dalam meningkatkan volume penjualan susu dari Mitra 2 (peternak sapi).

Kualitas susu yang telah memenuhi standar kualitas nasional mempunyai dampak positif pada peningkatan penjualan baik pada Mitra 1 dan Mitra 2 . Bagi mitra 1, permintaan susu muncul dari para mahasiswa dan anak-anak muda. Susu pasteurisasi dirasa lebih gurih dan tidak bau kandang. Sedangkan bagi Mitra 2, permintaan susu datang dari pembuat susu pasteurisasi Susu Poang dengan jumlah yang hampir sama dengan permintaan susu segar oleh Mitra 1. Dengan demikian volume penjualan susu segar di Mitra 2 (peternak) mengalami peningkatan karena ada pasar baru yaitu Susu Poang, sedangkan volume penjualan susu pasteurisasi Mitra 1 juga ada peningkatan karena ada pasar baru yaitu para mahasiswa dan anak-anak muda.

Peningkatan volume penjualan ini mendorong Mitra 1 untuk mencari informasi yang terkait dengan merk dagang dan mencari peluang passar baru, sedangkan Mitra 2 akan menjaga kualitas dan meningkatkan kualitas susu sehingga bisa menjaga hubungan dengan Mitra 1 dan pelanggan baru Susu Poang. Untuk mendukung aspek manajemen, ada peraltan yang diserahkan kepada Mitra 1 berupa lap top untuk mencatat transaksi keuangan dan mengembangkan jaringan berbasis internet, sedangkan bagi Mitra 2 yaitu dibuatkan sambungan listrik yang bisa digunakan untuk pendingin susu dan nota penjualan susu. Gambar 2 merupakan penyerahan lap top ke Mitra 1 dan Gambar 3 adalah susu segar yang memenuhi kualitas standar nasional.

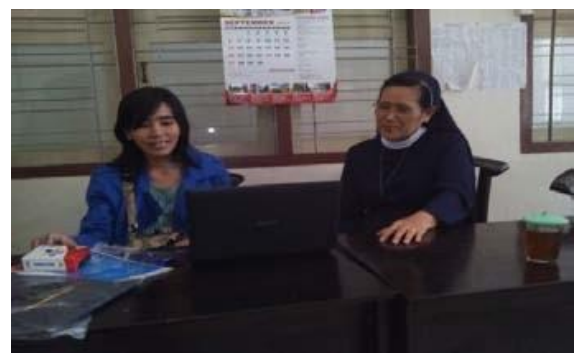

Gambar 2. Penyerahan lap top untuk pencatatan keuangan administrasi jaringan pemasaran

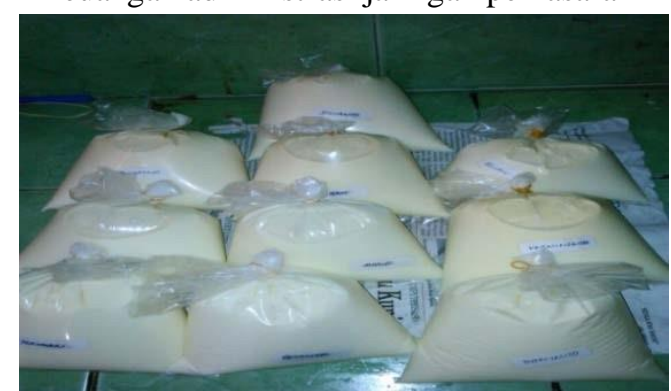

Gambar 3. Susu segar dari Mitra 2 yang memenuhi standar kualitas nasional

\section{KESIMPULAN DAN SARAN}

\section{Kesimpulan}

Kesimpulan sementara dari kegiatan yang sudah dilaksanakan selama ini adalah: (1).. Mitra baik Mitra 1 maupun Mitra 2 sangat antusias melaksanakan kegiatan dalam program IbM ini, karena terdorong keinginan untuk menjadi baik dalam mengembangkan usahanya di bidang susu segar maupun susu pasteurisasi;

(2). Beberapa indikator yang ditargetkan sudah tercapai, misalya dalam hal kualitas susu, semangat kewirausahaan dan indicator lainnya, kecuali terdaftarnya merek, karena masih memerlukan persyaratan secara fisik yang belum memenuhi.

\section{Saran}

Setelah melaksanakan program kegiatan ini dan melihat indikator keberhasilan yang telah dan masih diupayakan tercapai maka beberapa saran dapat disampaika sebagai berikut : (1).kebersihan dan kualitas susu masih perlu terus ditingkatkan, meskipun telah terjadi kenaikan kualitas susu selama program kegiatan ini; (2). Program pendampingan sebagai kelanjutan program kegiatan ini masih perlu dilanjutkan agar hal hal yang telah baik dapat dipertahankan bahkan ditingkatkan. Misalnya dengan selalu memotivasi mitra agar lebih produktif dan kreatif.

\section{DAFTAR PUSTAKA}

Asnudin, Andi, (2010)Pendekatan Program Partisipatif dalam Pembangunan Proyek Infrastruktur di Indonesia, Jurnal SMARTek, Vol. 8 No. 3. Agustus 2010: 182 $-190$

Rizky Al Fauzi, (2014) Penerapan Performance Assessment Dalam Kegiatan Praktikum Pembuatan Yoghurt Terhadap Pencapaian Standar Kompetensi Menggunakan Mikroorganisme Dalam Pengolahan (Fermentasi) Di SMK Negeri 1 Cidaun Universitas Pendidikan Indonesia repository.upi.edu | perpustakaan.upi.edu

Widodo W. (2002)Bioteknologi Fermentasi Susu. Malang. Pusat Pengembangan Bioteknologi Universitas Muhammadiyah Malang. 